\title{
Studies in the Bible and Antiquity
}

$1-1-2015$

\section{Scripture as Literature: Michael Austin's Job}

Jason A. Kerr

Follow this and additional works at: https://scholarsarchive.byu.edu/sba

\section{BYU ScholarsArchive Citation}

Kerr, Jason A. (2015) "Scripture as Literature: Michael Austin's Job," Studies in the Bible and Antiquity. Vol. 7, Article 4.

Available at: https://scholarsarchive.byu.edu/sba/vol7/iss1/4

This Article is brought to you for free and open access by the Journals at BYU ScholarsArchive. It has been accepted for inclusion in Studies in the Bible and Antiquity by an authorized editor of BYU ScholarsArchive. For more information, please contact scholarsarchive@byu.edu, ellen_amatangelo@byu.edu. 


\title{
Review Essay
}

\section{Scripture as Literature: Michael Austin's Job}

\author{
Jason A. Kerr
}

Review of Michael Austin. Re-reading Job: Understanding the Ancient World's Greatest Poem. Salt Lake City: Greg Kofford Books, 2014.

In RE-READing JoB, Michael Austin argues by both precept and example that literary methods afford a fruitful way of studying scripture. Austin is not the first Latter-day Saint to advocate such methods; in recent years several books have taken literary approaches to the Book of Mormon, drawing inspiration from books published in the early 1980s by Robert Alter and Northrop Frye that launched literary study of the Bible as a serious academic field. ${ }^{1}$ For all this flurry of activity, though, such ways of reading remain unfamiliar to many Latter-day Saints, perhaps due in part to wariness about treating familiar biblical

1. Richard Dilworth Rust, Feasting on the Word: The Literary Testimony of the Book of Mormon (Salt Lake City: Deseret Book and FARMS, 1997); Grant Hardy, Understanding the Book of Mormon: A Reader's Guide (New York: Oxford University Press, 2010); Robert Alter, The Art of Biblical Narrative (New York: Basic, 1981); Northrop Frye, The Great Code: The Bible and Literature (New York: Harcourt Brace Jovanovich, 1982). 
figures as literary characters or favorite narratives as stories rather than historical accounts. Literary methods, however, enrich the practice of reading scripture by inviting readers to become aware of how they read, and this awareness sends readers into the depths of the text in ways that can produce devotional readings that attend closely to the complexities of human life. In this way, as Austin's book amply shows, literary study of scripture provides a powerful means of affirming the continued relevance of scripture, even amidst historical change.

Becoming aware of how one reads includes grappling with questions of historicity and historicism. In chapter 2 of Re-reading Job, Austin takes the stance that questions of historicity are more or less uninteresting: "As Latter-day Saints ... we are free to seek our own inspiration in determining whether or not there was an actual man named Job who lived in a place called Uz.... I do not believe that the answer to this question matters" (p. 18). He then proceeds to build a case for reading Job as a fictional text because it begins with the Hebrew equivalent of "once upon a time," among myriad other details (including its problematic depiction of God). Fictional status does not, however, ipso facto undermine the book's connection with truth: "Acknowledged fictions can be assembled into narratives that convey profound-and trueinsights to those who read them" (p. 19). We can find, for instance, that Middlemarch conveys truth without our being obliged to believe in the historical existence of Dorothea Brooke or Edward Casaubon. More to the point, Jesus's parables can teach truth without requiring belief in the historical existence of a Samaritan who actually helped a wounded traveler on the road to Jericho. Such an approach assumes a transcendental, transhistorical truth that can be instantiated in vehicles whose accuracy or otherwise according to the methods of twenty-first-century historiography is of little moment.

Accordingly, it might appear that history matters little to literary readers of scripture, but such need not be the case. Austin draws on scholarship that locates the origins of the Job frame tale (the prose sections in chapters 1,2, and the end of 42) in Persian folklore, but his reading also relies on the insights of historical biblical criticism, 
particularly the notion that Israelite religion was a multifarious business in which Deuteronomistic, Priestly, and Wisdom schools of thought (however loosely defined) offered postexilic Jews different ways of understanding their national situation, history, and present obligations. Rather than treat this historical information merely as context, Austin (as would most literary scholars trained in the past three decades) understands that literature, whether fictional or factual, engages dialogically with its contexts, informing as well as being informed by them. In chapter 7 Austin presents the book of Job as an extended argument against the Deuteronomistic school, according to which the Babylonian exile resulted from Judah's breaking the covenant and thereby bringing on the curses described in Deuteronomy 28:47-57. In Austin's reading (which may oversimplify Deuteronomist thought), both Job and his comforters believe in what Latter-day Saints call "the law of the harvest"-the friends insist that Job's suffering means he must have done something wrong, and Job accuses God of injustice for punishing an innocent man. The Job poet, in Austin's reading, invites readers to see that the world is more morally complex than the law of the harvest allows, telling "the story of a man who thinks he is living in the world of Proverbs but finds himself trapped in that of Ecclesiastes with no way to escape" (p. 143). Thus, the book of Job offers a critique of what Austin describes as its host culture's prevailing religious orthodoxy, inviting readers to reject pat answers and to learn, instead, to ask more probing questions about the nature of God, the underpinnings of moral thought and practice, and so on. In this way, historically aware literary readings can send those who use them into processes of moral reasoning that, done well, can produce people able to respond with thoughtful faith to a complex range of human experiences.

The above claims hinge more on historical awareness than specific literary practice, however, which has to do with careful attention to the consequences of texts being written in a particular way. An immediate complication arises in that most Latter-day Saints do not have the training to read biblical texts in their original languages but must instead engage through the mediation of translation-a difficulty 
further amplified by the anglophone church's continued use of the four-hundred-year-old King James Version (KJV), which adds the challenge of navigating early modern English to the mix. Here, too, history comes into play, for the past century has seen considerable philological advances that put modern scholars in much better stead to make sense of the Hebrew text than were their Jacobean counterparts (and with regard to the New Testament we now have access to much better manuscripts than those available to the KJV translators). This is to say that even though literary readings are of course possible using the church's lightly annotated edition of the KJV, modern study bibles (especially ones with thorough notes) can make literary readings much easier.

One feature of Job in which literary and historical readings come together in enriching ways has to do with Satan, or rather ha-satan, "the satan." The definite article means that this word cannot be read as a proper name but instead refers to an office, "the adversary," or "the accuser." As Austin explains, “'The satan' is a member of God's royal court like 'the messenger' or 'the advisor,' known only by his function. ... $[\mathrm{He}]$ combines the functions of a district attorney and a star witness for the prosecution. His job is to keep the Kingdom of God safe by rooting out discontentment and sedition wherever it might be" (p. 35). Close attention to the text-noticing that definite article-prompts historical inquiry that then leads readers to divest the satan in Job of the diabolical trappings associated with his capitalized theological counterpart and instead understand this figure as a character in a story. This realization prompts the question of whether God in Job should also be treated as a literary figure rather than as a literal portrait of the true Deity, which raises the further question of genre: if Job isn't a historical account of an encounter between the one true God that other scriptures call us to worship and the capital-S Satan they invite us to spurn, what is it? Questions of this kind, and the insights that may follow them, are available to nonreaders of Hebrew only through study Bible annotations or similar secondary materials.

The question of just what sort of text Job happens to be illustrates another advantage of approaching scripture from a literary perspective, 
including the use of modern translations of the Bible. Scripture contains multiple genres, and being aware of genres and their conventions can make us more sensitive readers. The Bible obviously contains a range of genres: the tightly written prose narratives of Genesis, the historical accounts in Samuel and Kings, the law codes in Leviticus and Deuteronomy, a range of poetic forms in the Psalms, satire in Jonah, literary prophecy of various kinds, and so on. Richard Rust has extended this kind of generic analysis to the Book of Mormon, analyzing its use of sermons, letters, and other forms. Attention to genre could also inform readings of the Doctrine and Covenants, which contains personal addresses of the sort addressed to Oliver Cowdery in section 6, ecclesiological instructions (e.g., sections 20 and 107), letters (sections 121-23), conciliar declarations (section 134), and press releases (section 135), among others. In Job, the most important generic point (aside from observing that it is a fictional account rather than a historically "true" one) is the text's shifting from prose to poetry at the beginning of chapter 3 and back to prose at 42:7. This is a shift that readers of the KJV, which uniformly renders the book in its lovely prose, will miss altogether.

The best way for people who don't read Hebrew to attune themselves to literary features of biblical texts is therefore to engage with multiple translations. The KJV should remain part of the picture, not only because it is the Bible with which most anglophone Latter-day Saints are most familiar, but also because, as Ronan Head observes, its language undergirds modern LDS scripture. ${ }^{2}$ Putting modern translations like the New Revised Standard Version or the Jewish Publication Society (JPS) Tanakh-especially when these are published in study bible format complete with annotations-into conversation with the KJV can attune non-Hebrew readers to nuances of the text, especially

2. Ronan James Head, “Unity and the King James Bible," Dialogue 45/2 (2012): 45-58. On the history of Latter-day Saints and the King James Bible, see Philip L. Barlow, "Why the King James Version? From the Common to the Official Bible of Mormonism," Dialogue 22/2 (1989): 19-43, expanded in Barlow, Mormons and the Bible: The Place of the Latter-day Saints in American Religion (1991; repr., New York: Oxford University Press, 2013). 
where the Hebrew is difficult to translate, as happens frequently in Job. These translations, needless to say, render Hebrew verse as English verse and thus make at least that generic shift easier to notice. Anyone interested in literary readings, though, should be sure to include Robert Alter's translations in their collection of bibles. ${ }^{3}$ Alter translates with the goal of making the English represent the literary features of the Hebrew as nearly as possible, explaining his thought process in copious notes. There is no real substitute for reading the Hebrew, but comparing multiple translations (especially when Alter's is among them) inculcates in readers an awareness of the mediation that translation performs while, somewhat paradoxically, also getting us as close to the original as possible without learning Hebrew.

Awareness of how translation affects scriptural meaning opens the door to a deeper awareness of how we habitually read in the first place. Sometimes the dislocation of encountering a new translation is all it takes to help us see that we perhaps hadn't quite thought through our interpretation of a particular passage. Austin's strongest case in point from Job is 19:25, which the KJV renders as "For I know that my redeemer liveth, and that he shall stand at the latter day upon the earth." The LDS Old Testament Gospel Doctrine manual reads this passage as being transparently about Jesus Christ, indeed going so far as to use it for the title of the Job lesson. ${ }^{4}$ The JPS Tanakh, meanwhile, gives the passage as "But I know that my Vindicator lives; in the end He will testify on earth." Alter's translation comes closer to the KJV— "But I know my redeemer lives, / and in the end he will stand up on earth"-but his note adds crucial context:

This famous line, long the subject of Christological interpretation, in fact continues the imagery of a legal trial to which Job reverts so often. The redeemer is someone, usually a family member,

3. Michael Austin, personal communication to author, April 28, 2015. Although Austin quotes from the New Jewish Publication Society Tanakh, he prefers Alter's translation, which licensing fees prevented him from using in the book.

4. Old Testament: Gospel Doctrine Teacher's Manual (Salt Lake City: The Church of Jesus Christ of Latter-day Saints, 2001), 157-61. 
who will come forth and bear witness on his behalf, and the use of "stand up" in the second verset has precisely that courtroom connotation. $^{5}$

Alter soft-pedals the point somewhat, half-countering the christological reading without quite explaining why it doesn't work. Austin builds on this context and philological investigation of the word translated "redeemer" ( $g o^{3} \mathrm{el}$, a form of $\left.g a^{3} a l\right)$ to drive the implications home:

There are many scenarios in which an Old Testament figure might plausibly talk about the prophesied Messiah as a ${ }^{3} a^{3}$ al. But Job 19:25 is not one of them.... Job is not looking for someone to redeem him from his sinful human nature or from spiritual bondage. He wants someone to testify on his behalf to convince God that he did not do whatever God thinks he did-and therefore to restore, if only posthumously, both his reputation and his estate. (pp. 105-6)

That is, Job is looking for an avenger of blood (another possible translation of $\mathrm{go}^{\mathrm{C}} \mathrm{el}$ ) to vindicate him against God. He isn't expressing faith in God but rather in someone who will correct the injustice he believes that God has done to him.

This interpretation calls habituated Christian ways of reading the passage sharply into question. One need not agree with Austin's reading for the desired effect to occur: instead of seeing the word redeemer and immediately assuming Jesus, we pause and think again. We consider the surrounding verses. Although the Gospel Doctrine manual includes the whole of chapter 19 in the assigned reading, the lesson plan refers only to verses 25-27, omitting 21, which clearly identifies God as the entity Job blames for his afflictions: "Pity me! Pity me! You are my friends; For the hand of God has struck me!" (NJPS). ${ }^{6}$ This is to say nothing of the litany of complaints directed at God in verses 8-13. Admittedly, a christological reading is still possible in light of this knowledge, but producing one

5. Robert Alter, The Wisdom Books: Job, Proverbs, and Ecclesiastes (New York: Norton, 2010), 83-84.

6. Old Testament: Gospel Doctrine Teacher's Manual, 159. 
demands more thought and care than simply identifying the "redeemer" with Jesus. One possibility requires accounting for a malicious God whom Jesus will placate on our behalf. Alternatively, reading in light of God's stern rebuke of Job in the theophany that concludes the poem, we could think about how Jesus engages in our lives when we completely misunderstand how God works-an approach that would require thinking about God in Job as a character we're supposed to critique rather than as an accurate depiction of Deity. The superficial "redeemer = Jesus" reading has been uplifting Christians for fifteen hundred years and shouldn't be dismissed too casually, and yet getting beyond the surface of this famous passage opens up opportunities for a grittier theological account of what part Jesus plays in human-divine relationships. Literary approaches to scripture value this kind of deep dive into the text and the difficult questions it raises when put to close scrutiny.

By inviting readers to slow down before reaching homiletic conclusions, literary approaches work in harmony with the long-standing Jewish (and related Christian) interpretive practice known as PaRDeS, an acronym for Peshat (literal reading), Remez (allegorical reading), Derash (homiletic reading), and Sod (mystical reading). This method distinguishes literal reading (peshat) from spiritual readings (the other three), with the idea that one ought to pursue peshat before moving on to the others-in part because peshat is the best way of learning that other kinds of reading are necessary. ${ }^{7}$ Such literal reading sounds easy, but as the example of Job 19:25 illustrates, it requires painstaking attention, often involving research with spurs shooting off in several directions. A literary approach adds to the possibilities peshat might explore by adding literary interpretations to the mix. As John Crawford points out, Austin's book is more a reception history of Job than a close reading, drawing readers' attention to a range of literary retellings of and responses to the book of Job. ${ }^{8}$ Rewritings-like Franz Kafka's The Trial or Robert

7. For instance, Maimonides' Guide to the Perplexed is an extended exercise in showing that passages with problematic peshat readings require allegorical interpretation of various kinds.

8. John Crawford, “Job: A Useful Reading," Dialogue 48/1 (2015): 153-56. 
Frost's A Masque of Reason-attest particular ways of reading that can help readers see the scriptural text in new ways after encountering the literary adaptations. Such work can lay the foundation for homiletic interpretations that respond powerfully to the complexities of human life by attending closely to the complexities of the scriptural text.

Austin's book does peshat well at a macro level, if not so much at the micro level. He devotes four chapters (out of ten), comprising about 60 pages (out of 150) to reading Job, a book of 42 chapters that (including the introduction) occupies 66 rather larger pages in the Jewish Study Bible. These chapters aim to present the big picture of a prose frame tale, a Wisdom dialogue in verse, some odds and ends, and the concluding theophany, doing just enough close reading to give readers a reasonably detailed but still broad sense of how the book as a whole works. The Wisdom dialogue, at 24 chapters comprising well over half the book, receives 15 pages. This forest-rather-than-trees approach is useful for readers accustomed to thinking of Job as the frame tale with a christological verse dropped somewhere in the vast unknown of the middle chapters, and it provides a fair enough peshat reading of the book as a whole to serve as the launching pad for the applied readings of the final four chapters. Chapter 7 reads the book of Job as a critique of the law of the harvest, arguing that it privileges kindness to friends over defending religious orthodoxy, including the justice of God. Austin takes on the familiar reading of 19:25 in chapter 8, arguing that even though this verse does not testify of Christ, the book's universalism, its parallels with the Sermon on the Mount and the parable of the Good Samaritan, and its acknowledgement of the need for reconciliation between humans and God make it the most profoundly Christian book in the Old Testament. Chapter 9 explores uses of Job to construct (or critique) theodicies in the wake of the Holocaust, including literary works that put God on trial, arguing that we shouldn't use the idea of God to dismiss other people's suffering. Finally, in chapter 10 Austin works to situate Job in the complex category of biblical Wisdom Literature before advancing a final argument that imaginative literature is not at all incompatible with divine revelation. These chapters present compelling 
arguments, and chapters 9 and 10 especially show the kind of payoff that careful attention to the text can yield. Sometimes careful attention undercuts familiar ideas-for instance, that 19:25 refers to Jesus-but it can also replace those ideas with more robust ones: a message of God's love for all his children, an ethic of care for the suffering.

Austin's focus on the big picture serves as a helpful introduction to deeper study of Job, upon which readers will learn, perhaps unsurprisingly, that Job is even more complicated than Austin allows. He writes frequently that Job is a great poem, but he does not do quite enough analysis of how the poem works or what makes it great. The concluding theophany is indeed sublime poetry, but Austin limits himself to higher-order analysis, simply saying that the point of chapters 38 and 39 is to demonstrate God's greatness. Austin notes that scholars have been underwhelmed with God's response to Job's questions; however, he suggests that God does respond to Job's accusations of injustice. A closer look challenges this perspective by, for example, bringing out God's sarcasm, which turns Job into the Deity's rhetorical plaything. One instance of sarcasm appears in 38:19-21:

Where is the way that light dwells, and darkness, where is its place, that you might take it to its home and understand the paths to its house?

You know, for you were born then, and the number of your days is great! (Alter)

Given that the frame tale makes God complicit in Job's suffering, this concluding insistence on the length of his days is nothing short of cruel. First of all, the line's sarcastic tone means that God is suggesting that Job's life will not be so long after all, which can only call to mind the divinely permitted deaths of his children. God's calling oblique attention to his own arbitrariness in allowing Job's suffering hardly provides an effective defense against accusations of injustice.

In a further passage, thick with irony, God invites Job to prove his own strength by crushing proud people in an angry fit: 
If you have an arm like God's, and with a voice like His you can thunder,

put on pride and preeminence, and grandeur and glory don.

Let loose your utmost wrath, see every proud man, bring him low.

See every proud man, make him kneel, tramp on the wicked where they are.

Bury them in the dust together, shut them up in the grave.

And I on my part shall acclaim you, for your right hand triumphs for you. (40:9-14 Alter)

Perversely, God will acknowledge the righteousness of Job's cause only if Job does to others what God has done to him. That is, God offers to vindicate his own justice by implicating Job in similar behavior. How, after all, is the theophanic show of force, whose stated purpose is to correct one "that darkens counsel by words without knowledge" (38:2 NRSV), anything other than a rather petulant crushing of human pride?

Austin acknowledges readings, notably Jung's, that find the theophany dissatisfying, but his attempted defense-at least God shows up!underserves the Job poet's achievement in passages like these. By portraying a God who is just as all-powerful as he claims, but who uses that power to rub Job's face in the very suffering that he allowed the satan to inflict, the poem invites readers to scrutinize their deepest beliefs. Such scrutiny happens through both literary and theological reflection, intertwining the processes of figuring out what the text actually says and working through the theological implications of various possible meanings. Austin credits the Job poet with greater moral complexity than any of the characters in the poem individually possess, which means that the poem's moral insights can only be discovered through careful reading, accompanied by lots of questions. Literary approaches to scripture involve ongoing dialogue between making sense of texts and working out their applications. These applications need not be devotional, but they certainly can be, and given that devotional readings do and should 
play a central part in Latter-day Saint communal life, literary methods recommend themselves as ways of producing readings adequate to the complexities and difficulties of our lives. Austin shows the potential that this approach has, and he invites readers to walk farther down the path to which his book opens the gate.

Jason A. Kerr is assistant professor of English at Brigham Young University, where he teaches early modern British literature and literary studies of the Bible. 